\title{
Karakteristik Buah Melon (Cucumis melo L.) pada Lima Stadia Kematangan
}

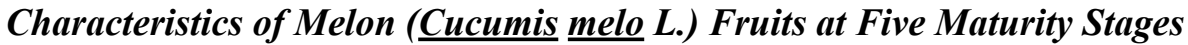

\author{
Amalia Nurul Huda ${ }^{1}$, Willy Bayuardi Suwarno ${ }^{2,3^{*}}$, dan Awang Maharijaya ${ }^{2,3}$ \\ ${ }^{1}$ Program Studi Pemuliaan dan Bioteknologi Tanaman, Sekolah Pascasarjana, Institut Pertanian Bogor \\ ${ }^{2}$ Departemen Agronomi dan Hortikultura, Fakultas Pertanian, Institut Pertanian Bogor \\ (Bogor Agricultural University), Jl. Meranti, Kampus IPB Darmaga, Bogor 16680, Indonesia \\ ${ }^{3}$ Pusat Kajian Hortikultura Tropika, Lembaga Penelitian dan Pengabdian kepada Masyarakat, Institut Pertanian Bogor \\ (Bogor Agricultural University), Jl. Raya Pajajaran, Bogor 16141, Indonesia
}

Diterima 23 Juli 2017/Disetujui 30 Juli 2018

\begin{abstract}
Melon breeding for fruit quality improvement is important to produce new varieties suitable for consumers'demand. The aim of this study was to elucidate fruit characteristics of melon at five different maturity stages, involving several genotypes belonging to two cultivar groups: reticulatus and inodorus. The experiments were conducted in three planting seasons: (1) January-March 2015 (13 genotypes), (2) December 2015-February 2016 (56 genotypes), (3) February-May 2016 (9 genotypes). These trials were conducted at the Tajur II experimental station of IPB, Bogor, and each trial was arranged in a single factor randomized complete block design with three blocks. Maturity stages was determined based on fruit rind color and net coverage, and their effects on fruit quality were studied using combined analyses over seasons. Maturity stage significantly affected the fruit length, fruit diameter, flesh thickness, fruit weight, and sugar content. The average weight of the fruits at maturity stage $4(838.90 \mathrm{~g})$ and $5(931.79 \mathrm{~g})$ was significantly greater than that of stage $1(584.42 \mathrm{~g})$. The sugar content increased from maturity stage $2\left(5.51^{\circ} \mathrm{Brix}\right)$ to $3\left(6.13^{\circ} \mathrm{Brix}\right)$ and to $5\left(8.18^{\circ} \mathrm{Brix}\right)$. Fruit weight significantly correlated with fruit length $(r=0.53)$, fruit diameter $(r=0.85)$, fruit rind thickness $(r=0.33)$, and flesh thickness $(r=0.63)$. Maturity stages affected the quality of melon fruits, and therefore appropriate harvesting criteria need to be determined in melon cultivations.
\end{abstract}

Keywords: cantalupensis, correlation, inodorus, fruit quality

\section{ABSTRAK}

Pemuliaan melon untuk perbaikan kualitas buah penting untuk menghasilkan varietas baru yang memenuhi permintaan konsumen. Tujuan penelitian ini adalah mengetahui karakteristik buah melon pada lima stadia kematangan yang berbeda, dengan menggunakan beberapa genotipe yang termasuk dalam dua kelompok kultivar: reticulatus dan inodorus. Penelitian dilakukan dalam tiga musim tanam: (1) Januari-Maret 2015 (13 genotipe), (2) (Desember 2015-Februari 2016 (56 genotipe), (3) Februari-Mei 2016 (9 genotipe). Ketiga percobaan dilaksanakan di Kebun Percobaan IPB Tajur II, Bogor, masingmasing menggunakan rancangan kelompok lengkap teracak faktor tunggal dengan tiga kelompok. Stadia kematangan buah ditentukan berdasarkan warna kulit buah dan intensitas jala pada permukaan kulit buah, dan pengaruhnya terhadap kualitas buah dipelajari melalui analisis gabungan antar musim. Stadia kematangan berpengaruh nyata terhadap karakter panjang buah, diameter buah, tebal daging buah, bobot buah, dan padatan terlarut total. Nilai tengah bobot buah pada stadia kematangan 4 (838.90 g) dan 5 (931.79 g) menunjukkan berbeda nyata lebih besar dari stadia 1 (584.42 g). Pengaruh stadia kematangan terhadap padatan terlarut total ditunjukkan oleh perubahan stadia kematangan $2\left(5.51^{\circ}\right.$ Brix) ke 3 (6.13 ${ }^{\circ}$ Brix) serta perubahan stadia kematangan ke $5\left(8.18^{\circ}\right.$ Brix). Bobot buah berkorelasi nyata dengan panjang buah $(r=0.53)$, diameter buah $(r=0.85)$, tebal kulit buah $(r=0.33)$, dan tebal daging buah $(r=0.63)$. Stadia kematangan berpengaruh terhadap kualitas buah sehingga perlu ditentukan kriteria panen yang tepat dalam budidaya melon.

Kata kunci: cantalupensis, inodorus, korelasi, kualitas buah

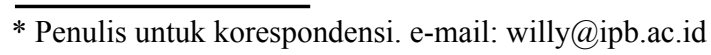




\section{PENDAHULUAN}

Melon (Cucumis melo L.) merupakan buah yang memiliki beberapa kandungan vitamin dan mineral yang bermanfaat bagi kesehatan tubuh. Melon jenis cantaloupe merupakan salah satu sumber vitamin $\mathrm{C}$, vitamin $\mathrm{A}$, kalium, vitamin B6, asam folat, dan niasin. Kandungan vitamin $\mathrm{A}$ dan vitamin $\mathrm{C}$ pada buah melon jenis cantaloupe masingmasing adalah $54 \%$ dan $49 \%$ dari angka kecukupan gizi harian. Kandungan mineral pada buah melon antara lain kalium, kalsium, besi, magnesium, fosfor, natrium, dan zink. Warna daging buah oranye pada melon mengindikasikan adanya kandungan karotenoid yang bermanfaat untuk kesehatan jantung dan sistem imun tubuh, sedangkan melon yang daging buahnya berwarna hijau ada yang mengandung vitamin B6 yang bermanfaat untuk menjaga kekuatan tulang dan gigi (USDA, 2016).

Melonmemilikikarakterbuah dengankeragamantinggi (Szamosi et al., 2010). Keragaman karakter buah tersebut meliputi bentuk, ukuran, warna kulit dan daging buah, tekstur kulit, padatan terlarut total, aroma, dan perbedaan jenis buah berdasarkan produksi etilen (klimakterik dan non klimakterik). Melon dikelompokkan menjadi beberapa grup kultivar, dan tiga diantaranya yang populer di Indonesia yaitu $C$. melo var. reticulatus, $C$. melo var. inodorus, dan C. melo var. cantalupensis (Robinson and Decker-Walters, 1999; Suwarno et al., 2017). Kelompok reticulatus memiliki kulit buah berjala, daging buah umumnya hijau atau oranye, ada yang beraroma tetapi tidak lebih kuat dibandingkan melon cantalupensis. Kelompok inodorus tidak memiliki jala pada kulit buah, buah tidak lepas dari tangkainya ketika masak, tekstur daging buah renyah, dan daya simpan buah relatif lama. Kelompok cantalupensis umumnya memiliki juring pada buahnya, sedikit berjala, daging buah umumnya berwarna oranye, buah yang masak akan terlepas dari tangkainya, aroma buah wangi dan kuat, dan tekstur daging buah lembut (Robinson and Decker-Walters, 1999; Liu et al., 2004; Suwarno et al., 2017) .

Kelompok melon reticulatus dan cantalupensis dengan karakter buah klimakterik umumnya memiliki umur simpan (shelf life) lebih pendek dari kelompok melon inodorus yang non-klimakterik. Penanganan pascapanen untuk melon klimakterik perlu lebih diperhatikan untuk mencegah rusaknya buah melon akibat transportasi dan lamanya penyimpanan. Umur simpan buah melon menunjukkan korelasi yang nyata dengan karakter ukuran buah, ukuran benih, padatan terlarut total, warna daging buah, dan perubahan warna pada permukaan buah (Liu, et al., 2004).

Faktor lain yang mempengaruhi umur simpan adalah stadia kematangan buah. Kualitas buah seperti bobot buah dan padatan terlarut total diduga dipengaruhi oleh stadia kematangan. Oleh sebab itu stadia kematangan buah merupakan hal penting yang perlu diperhatikan pada budidaya melon. Padatan terlarut total pada buah melon tidak akan mengalami peningkatan setelah buah dipanen, karena padatan terlarut total akan diperoleh saat buah masih pada tangkai hingga kematangan buah yang maksimal (Mutton et al., 1981).
Tujuan percobaan ini adalah: (1) mempelajari karakteristik buah melon pada lima stadia kematangan buah, dan (2) mengembangkan model persamaan regresi linier untuk memprediksi nilai karakter kuantitatif buah berdasarkan stadia kematangan. Variasi stadia kematangan pada penelitian ini umumnya terjadi akibat serangan penyakit terutama embun bulu (downy mildew) dan embun tepung (powdery mildew). Permodelan karakteristik buah khususnya bobot dan padatan terlarut total dapat bermanfaat untuk memprediksi besarnya peningkatan karakter-karakter buah tersebut pada setiap kenaikan stadia kematangan, pada pertanaman dengan kendala yang serupa.

\section{BAHAN DAN METODE}

Percobaan dilaksanakan di Kebun Percobaan IPB Tajur II, Bogor yang terletak pada \pm 310 mdpl dan memiliki jenis tanah latosol. Penelitian dilakukan dalam tiga musim tanam, yaitu 1) Januari-Maret 2015 menggunakan 13 genotipe, 2) Desember 2015-Februari 2016 menggunakan 56 genotipe, dan 3) Februari-Mei 2016 menggunakan 9 genotipe. Percobaan tersebut dilakukan pada lokasi yang sama dan masing-masing menggunakan rancangan kelompok lengkap teracak (RKLT) faktor tunggal (stadia kematangan) dengan tiga kelompok. Analisis gabungan antar musim dilakukan untuk mempelajari pengaruh perbedaan karakter buah melon pada stadia kematangan dan musim tanam yang berbeda.

Musim tanam pertama menggunakan 13 genotipe yang terdiri atas 10 genotipe melon tipe reticulatus dan 3 genotipe melon tipe inodorus. Musim tanam kedua menggunakan 56 genotipe yang terdiri atas 38 genotipe melon tipe reticulatus dan 18 genotipe melon tipe inodorus. Musim tanam ketiga menggunakan 9 genotipe yang terdiri atas 1 genotipe melon tipe reticulatus dan 8 genotipe melon tipe inodorus (Tabel 1). Jumlah buah dengan stadia 1 hingga 5 masing-masing adalah, 183 buah, 124 buah, 87 buah, 74 buah, dan 40 buah.

Persiapan lahan dilakukan melalui tahap pengolahan tanah, pembersihan lahan dari sisa tanaman dan gulma, serta pembuatan bedengan. Pupuk dasar yang diberikan berupa 20 ton pupuk kandang ha-1, $200 \mathrm{~kg}$ urea ha-1, $200 \mathrm{~kg} \mathrm{SP-36}$ $\mathrm{ha}^{-1}$, dan $200 \mathrm{~kg} \mathrm{KCl} \mathrm{ha-1}$. Bedengan ditutup dengan mulsa plastik hitam perak kemudian dibuat lubang tanam dengan jarak tanam $60 \mathrm{~cm} \times 60 \mathrm{~cm}$. Penanaman dilakukan di sore hari untuk menghindari tanaman stres akibat terik matahari. Pemangkasan cabang lateral dilakukan kecuali pada cabang ke-9 sampai ke-12. Pupuk susulan berupa pupuk NPK dalam bentuk larutan (konsentrasi $20 \mathrm{~g} \mathrm{~L}^{-1}$ air; $200 \mathrm{ml}$ per tanaman) yang diberikan di pangkal batang tanaman pada 7, 14, 21, 28, 35, 42, dan 49 hari setelah tanam (HST), dan pupuk $\mathrm{KNO}_{3}$ pada $45 \mathrm{HST}$ (konsentrasi $5 \mathrm{~g} \mathrm{~L}^{-1}$ air; $200 \mathrm{ml}$ per tanaman). Ketiga percobaan dilaksanakan menggunakan teknik budidaya seperti yang dikemukakan oleh Sobir dan Siregar (2014) yang dimodifikasi.

Stadia kematangan buah ditentukan berdasarkan warna kulit buah dan intensitas jala pada permukaan kulit buah dengan memberikan skor dari 1 (tidak matang) hingga 5 (matang sempurna) (Tabel 2). Warna kulit buah melon 
Tabel 1. Materi genetik melon yang digunakan pada tiap musim tanam

\begin{tabular}{llccccc}
\hline Tipe melon & \multicolumn{1}{c}{$\begin{array}{c}\text { Musim } \\
\text { tanam }\end{array}$} & $\begin{array}{c}\text { Jumlah } \\
\text { genotipe }\end{array}$ & $\begin{array}{c}\text { Jumlah } \\
\text { buah }\end{array}$ & $\begin{array}{c}\text { Umur berbunga } \\
\text { hermaprodit } \\
(\text { HST })\end{array}$ & $\begin{array}{c}\text { Bobot buah } \\
(\mathrm{g})\end{array}$ & $\begin{array}{c}\text { Padatan terlarut } \\
\text { total }\left({ }^{\circ} \text { Brix }\right)\end{array}$ \\
\hline Cantalupensis & 1. Jan-Mar 2015 & 10 & 114 & 35 & 929.80 & 7.32 \\
& 2. Des 2015-Feb 2016 & 38 & 126 & 33 & 729.56 & 4.33 \\
& 3. Feb-Mei 2016 & 1 & 5 & 34 & 513.6 & 4.25 \\
Inodorus & 1. Jan-Mar 2015 & 3 & 38 & 35 & 700.79 & 8.28 \\
& 2. Des 2015-Feb 2016 & 18 & 144 & 33 & 711.76 & 5.78 \\
& 3. Feb-Mei 2016 & 8 & 98 & 34 & 533.94 & 5.18 \\
\hline
\end{tabular}

kelompok inodorus dibedakan menjadi dua, yaitu kuning dan putih. Buah yang tidak matang memiliki ciri-ciri warna permukaan buah tidak cerah (misalnya kuning kehijauan atau warna putih yang belum menjadi krem) dan intensitas jala yang sedikit (untuk melon tipe reticulatus). Ciri-ciri buah yang matang sempurna yaitu warna permukaan kulit buah cerah (misalnya kuning tua atau krem) dan intensitas jala yang tinggi atau menutupi seluruh permukaan buah (untuk melon tipe reticulatus). Hal ini sesuai dengan pernyataan Cuevas et al. (2010) serta Sobir dan Siregar (2014) bahwa kematangan buah melon inodorus ditandai dengan perubahan warna permukaan buah dari warna hijau tua menjadi putih atau kuning.

Karakter buah yang diamati meliputi panjang buah $(\mathrm{cm})$, diameter buah $(\mathrm{cm})$, tebal daging buah $(\mathrm{cm})$, tebal kulit buah $(\mathrm{cm})$, bobot buah $(\mathrm{g})$, dan padatan terlarut total ( $\left.{ }^{\circ} \mathrm{Brix}\right)$. Pengamatan karakter-karakter tersebut mengacu pada Descriptor for Melon (Cucumis melo L.) (IPGRI, 2003). Analisis peragam gabungan antar percobaan dilakukan menggunakan data per tanaman dengan sumber keragaman musim, ulangan dalam musim, stadia kematangan, dan interaksi musim $\times$ stadia kematangan, ditambah dengan

Tabel 2. Karakter morfologi buah melon pada lima stadia kematangan

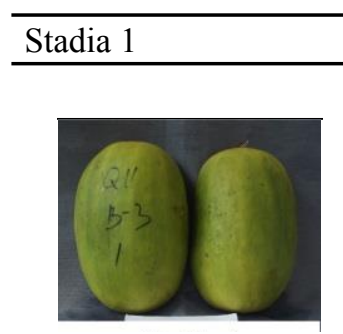

Stadia 1

Warna buah hijau, terdapat bulu halus pada permukaan buah dan sedikit lengket

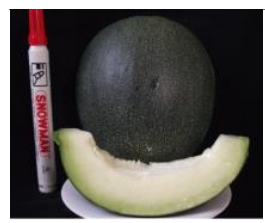

Stadia 1

Tidak terdapat jala pada permukaan buah, tangkai buah belum lepas, dan terdapat bulu pada permukaan buah, permukaan sedikit lengket

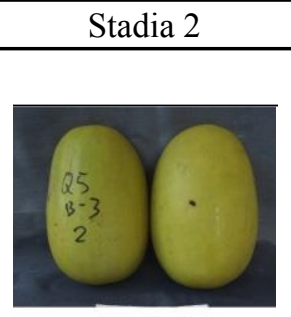

Stadia 2

Warna buah kuning muda dan terdapat sedikit bulu halus pada permukaan buah.

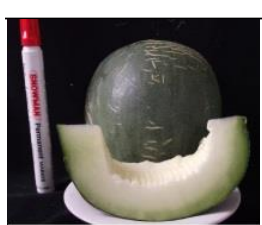

Stadia 2

Terdapat sedikit jala pada permukaan buah, tangkai buah belum lepas, dan terdapat bulu pada permukaan buah.

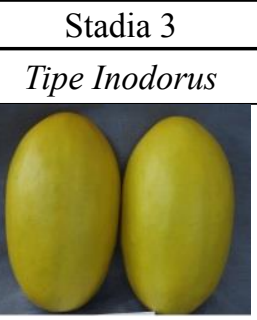

Stadia 3

Warna buah kuning, tidak terdapat bulu pada permukaan buah, halus.

dan sedikit halus.

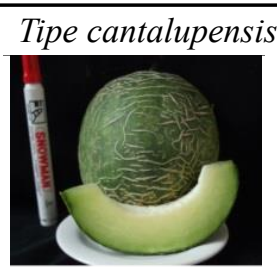

Stadia 3

Terdapat jala dengan intensitas sedang dan tangkai buah belum lepas.

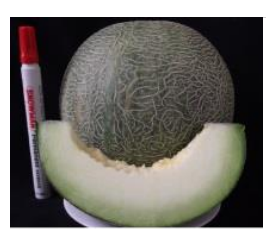

Stadia 4

Terdapat jala dengan intemsitas banyak dan tangkai belum lepas.

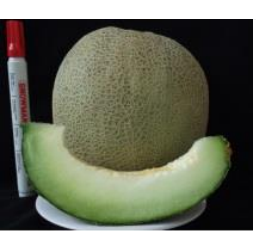

Stadia 5
Terdapat jala dengan intensitas banyak dan distribusi jala yang merata pada seluruh permukaan buah, serta tangkai buah lepas.
Warna buah

kuning cerah dan permukaannya halus 
genotipe dalam musim sebagai peragam. Analisis korelasi dan regresi digunakan untuk mengetahui hubungan antara stadia kematangan dengan karakter kuantitatif buah yang diamati. Perangkat lunak yang digunakan untuk analisis data adalah SAS.

\section{HASIL DAN PEMBAHASAN}

Kisaran waktu panen buah melon pada tiap musim percobaan tidak terlalu jauh, kecuali pada musim 1 (61-79 HST). Rentang waktu panen pada musim 2 adalah 63-65 HST, sedangkan pada musim ketiga, seluruh buah yang diamati dipanen pada umur 67 HST. Perbedaan stadia kematangan buah lebih disebabkan oleh ketahanan tanaman karena serangan penyakit embun bulu (downy mildew), yang disebabkan oleh cendawan Pseudoperonospora cubensis (Berk. \& Curtis) Rostovzev, atau embun tepung (powdery mildew) yang disebabkan oleh cendawan Erysiphe cichoracearum. Serangan penyakit-penyakit tersebut ditemui pada ketiga musim tanam dengan intensitas yang berbeda-beda, mengakibatkan kelayuan pada daun dan menyebabkan tanaman tidak dapat berfotosintesis dengan baik. Terhambatnya proses fotosintesis mengakibatkan perkembangan buah tidak optimal, sehingga sebagian besar buah dipanen sebelum mencapai masak fisiologis.

Hasil analisis ragam gabungan menunjukkan adanya pengaruh musim untuk karakter panjang buah, diameter buah, tebal daging buah, bobot buah, dan padatan terlarut total $(\mathrm{P}<0.01)$ (Tabel 3). Stadia kematangan menunjukkan pengaruh yang nyata terhadap panjang buah, diameter buah, tebal daging buah, bobot buah, dan padatan terlarut total, namun tidak nyata terhadap tebal kulit buah. Berdasarkan penelitian Feyzian et al. (2009), kematangan buah melon merupakan karakter yang ditentukan oleh aksi gen nonaditif, sedangkan bobot buah merupakan karakter yang dipengaruhi oleh aksi gen aditif. Genotipe dalam musim menunjukkan pengaruh yang nyata pada semua karakter.

Pengaruh interaksi antara musim dan stadia kematangan nyata terhadap panjang buah (Tabel 3). Hal ini antara lain disebabkan adanya tren peningkatan panjang buah dari stadia kematangan 1 ke stadia kematangan 5 pada musim 2, namun tidak pada musim 1 dan 3 (Gambar 1). Hal ini diduga disebabkan oleh jumlah buah inodorus yang diamati pada musim 2 lebih banyak dibandingkan dengan musim 1 dan 3 (Tabel 1). Melon tipe inodorus umumnya memiliki bentuk buah lonjong, sehingga tren peningkatan panjang buah lebih terlihat pada musim 2. Nilai tengah tertinggi panjang buah berdasarkan rata-rata pada ketiga musim terdapat pada stadia kematangan $4(13.56 \mathrm{~cm})$ dan 5 $(13.25 \mathrm{~cm})$. Pengaruh interaksi musim $\times$ stadia kematangan tidak nyata terhadap diameter buah, namun pengaruh utama stadia kematangan nyata. Rata-rata diameter buah tertinggi terdapat pada stadia kematangan $5(11.79 \mathrm{~cm})$ dan $4(11.36$ cm) (Tabel 4).

Perbedaan stadia kematangan tidak mempengaruhi tebal kulit buah, namun mempengaruhi tebal daging buah dan bobot buah. Pada stadia kematangan 5, rata-rata tebal kulit buah adalah $0.74 \mathrm{~cm}$. Rata-rata tebal daging buah pada stadia kematangan $3(1.90 \mathrm{~cm})$ tidak berbeda nyata dengan stadia $4(2.03 \mathrm{~cm})$ dan $5(2.18 \mathrm{~cm})$ (Tabel 5). Ratarata bobot buah pada stadia kematangan 1 (584.42 g) tidak berbeda nyata dengan stadia 2 (676.63 g), namun terjadi perubahan yang nyata pada stadia kematangan 3 (720.02 g) ke stadia kematangan 4 (838.90 g). Nilai tengah bobot buah pada stadia kematangan 4 tidak berbeda nyata dengan stadia kematangan 5 (931.79 g) (Tabel 6).

Interaksi antara musim dan stadia kematangan terhadap karakter padatan terlarut total menunjukkan pengaruh yang nyata (Tabel 3). Tren peningkatan padatan terlarut total pada stadia kematangan 1-5 lebih terlihat pada musim 2 dan 3 dibandingkan dengan musim 1 (Gambar 2). Nilai ratarata padatan terlarut total tertinggi pada musim 1,2 , dan 3 ditemukan pada stadia kematangan 5, masing-masing sebesar $8.36^{\circ}$ Brix, $8.67^{\circ}$ Brix, dan $7.52^{\circ}$ Brix. Pada rata-rata padatan terlarut total, pengaruh stadia kematangan terhadap padatan terlarut total ditunjukkan oleh perubahan stadia kematangan $2\left(5.51^{\circ}\right.$ Brix $)$ ke $3\left(6.13^{\circ}\right.$ Brix $)$ serta perubahan stadia kematangan 4 (6.73 ${ }^{\circ}$ Brix $)$ ke 5 (8.18 ${ }^{\circ}$ Brix). Stadia kematangan 1 (5.32 ${ }^{\circ}$ Brix) tidak menunjukkan perbedaan yang nyata dengan stadia kematangan 2 (Tabel 6).

Pada percobaan Abu-Goukh et al. (2011) kandungan gula pada melon jenis cantaloupe mencapai puncaknya

Tabel 3. Rekapitulasi nilai kuadrat tengah karakter kuantitatif buah

\begin{tabular}{lrrrrr}
\hline Karakter & \multicolumn{1}{c}{ Musim } & Genotipe (musim) & Stadia kematangan & $\begin{array}{c}\text { Musim } \times \text { stadia } \\
\text { kematangan }\end{array}$ & KK (\%) \\
\hline PB & $26.20^{* *}$ & $10.98^{* *}$ & $24.34^{* *}$ & $6.62^{* *}$ & 11.64 \\
DB & $72.94^{* *}$ & $7.38^{* *}$ & $24.16^{* *}$ & $1.06 \mathrm{tn}$ & 11.76 \\
TKB & $0.13^{*}$ & $0.09^{* *}$ & $0.03 \mathrm{tn}$ & $0.02 \mathrm{tn}$ & 25.32 \\
TDB & $5.91^{* *}$ & $0.59^{* *}$ & $1.19^{* *}$ & $0.19 \mathrm{tn}$ & 20.06 \\
BB & $1,115,385.26^{* *}$ & $226,343.80 * *$ & $566,265.60^{* *}$ & $43,336.19 \mathrm{tn}$ & 29.98 \\
PTT & $63.22^{* *}$ & $3.60 * *$ & $28.11^{* *}$ & $5.95^{* *}$ & 20.28 \\
\hline
\end{tabular}

Keterangan: $\mathrm{PB}=$ panjang buah; $\mathrm{DB}=$ diameter buah $\mathrm{TKB}=$ tebal kulit buah; $\mathrm{TDB}=$ tebal daging buah; $\mathrm{BB}=$ bobot buah; $\mathrm{PTT}=$ padatan terlarut total; $\mathrm{KK}=$ koefisien keragaman; * berpengaruh nyata pada taraf $5 \%$; ** berpengaruh nyata pada taraf $1 \%$; tn tidak berpengaruh nyata 


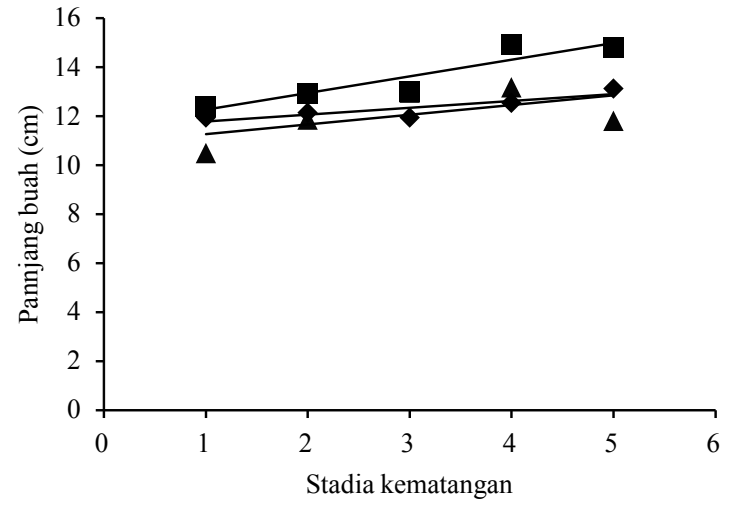

Gambar 1. Interaksi panjang buah dan stadia kematangan. M1 = Jan - Mar 2015; M2 = Des 2015 - Feb 2016; M3 = Feb - Mei 2016

pada 42 hari setelah antesis. Menurut Senesi et al. (2005) terdapat perbedaan padatan terlarut total pada sampel melon dengan stadia kematangan yang berbeda, yaitu stadia belum matang (unripe), stadia matang (ripe), dan stadia lewat matang (overripe). Perubahan tersebut terjadi pada kisaran $10^{\circ}$ Brix hingga $15^{\circ}$ Brix. Pada percobaan lain oleh Suketi et al. (2010), nilai padatan terlarut total buah pepaya umumnya mengalami peningkatan seiring dengan meningkatnya stadia kematangan buah. Meskipun demikian, Falah et al. (2015) mengemukakan bahwa peningkatan stadia kematangan buah pepaya tidak menyebabkan penigkatan kandungan karotenoid yang signifikan. Menurut Ezura dan Owino (2008), melon yang memiliki warna daging buah oranye umumnya menghasilkan produksi etilen yang lebih tinggi dibandingkan dengan melon yang memiliki warna daging buah hijau atau putih. Umumnya melon dengan warna daging buah hijau atau putih memiliki daya simpan yang lebih baik.

Karakteristik buah melon pada lima stadia kematangan buah dapat dibedakan berdasarkan tipe buah, yaitu reticulatus (berjala) dan inodorus (tanpa jala). Karakter buah yang menunjukkan perbedaan stadia kematangan antara lain adalah tingkat kecerahan warna buah pada tipe buah inodorus dan intensitas jala pada tipe buah reticulatus

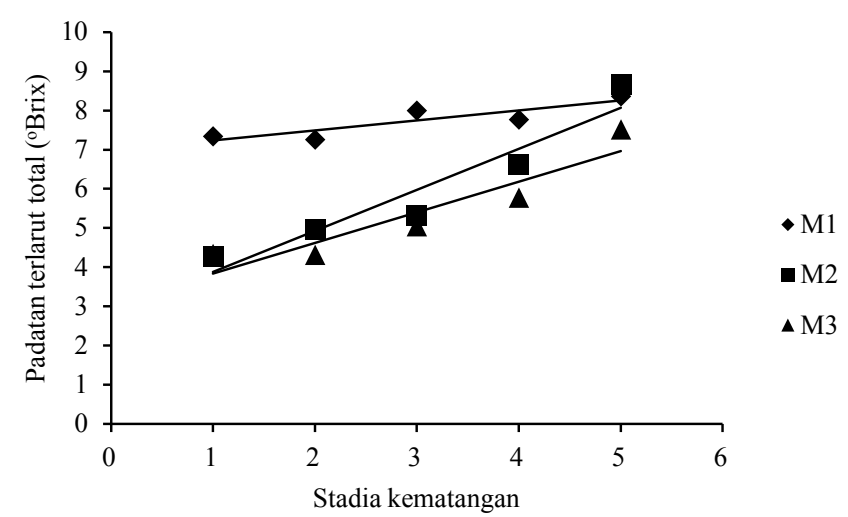

Gambar 2. Interaksi padatan terlarut total dan stadia kematangan. M1 = Jan - Mar 2015; M2 = Des 2015 - Feb 2016; M3 = Feb - Mei 2016

(Tabel 2). Hal ini sesuai dengan pernyataan Cuevas et al. (2010) bahwa kematangan buah melon inodorus ditandai dengan perubahan warna permukaan buah dari warna hijau tua menjadi hijau muda atau kuning. Selain warna permukaan buah dan intensitas jala, karakter lain seperti tangkai buah yang terlepas pada stadia kematangan 5 untuk tipe reticulatus juga dapat digunakan sebagai karakter yang membedakan stadia kematangan tersebut dengan stadia sebelumnya. Karakter lepasnya tangkai buah ini dikemukakan oleh Sobir dan Siregar (2014) sebagai kriteria panen, namun dalam percobaan ini karakter tersebut tidak diamati.

Kedua tipe buah melon juga dapat dibedakan berdasarkan karakter klimakterik untuk tipe reticulatus dan non-klimakterik untuk tipe inodorus. Hal ini sesuai dengan pernyataan Oh et al. (2011) bahwa melon yang memiliki jala pada permukaan buah menunjukkan produksi etilen yang lebih tinggi dibandingkan dengan melon tanpa jala. Menurut Pech et al. (2008) pemasakan buah (fruit ripening) dipengaruhi oleh beberapa faktor yang yang bersifat ethylene-dependent (sintesis aroma volatile, respirasi klimakterik, dan kondisi permukaan kulit buah) dan ethylene-independent (inisiasi klimakterik, akumulasi kandungan gula, pelepasan asam, dan warna daging buah).

Tabel 4. Nilai tengah panjang buah dan diameter buah pada untuk tiap stadia kematangan pada tiga musim tanam

\begin{tabular}{llllllrcc}
\hline \multirow{2}{*}{$\begin{array}{l}\text { Stadia } \\
\text { kematangan }\end{array}$} & \multicolumn{3}{c}{ Panjang buah $(\mathrm{cm})^{+}$} & \multicolumn{5}{c}{ Diameter buah $(\mathrm{cm})$} \\
\cline { 2 - 9 } & \multicolumn{1}{c}{ M1 } & \multicolumn{1}{c}{ M2 } & \multicolumn{1}{c}{ M3 } & Rata-rata & M1 & M2 & M3 & Rata-rata \\
\hline 1 & $11.94 \mathrm{abcd}$ & $12.41 \mathrm{bcd}$ & $10.49 \mathrm{~cd}$ & $11.61 \mathrm{~d}$ & 10.74 & 9.86 & 8.17 & $9.59 \mathrm{c}$ \\
2 & $12.15 \mathrm{abc}$ & $12.93 \mathrm{bcd}$ & $11.87 \mathrm{abc}$ & $12.31 \mathrm{bcd}$ & 11.53 & 10.56 & 8.40 & $10.16 \mathrm{bc}$ \\
3 & $11.94 \mathrm{abcd}$ & $13.01 \mathrm{bc}$ & $12.96 \mathrm{ab}$ & $12.63 \mathrm{bc}$ & 11.42 & 11.01 & 9.39 & $10.61 \mathrm{bc}$ \\
5 & $12.55 \mathrm{ab}$ & $14.94 \mathrm{a}$ & $13.19 \mathrm{a}$ & $13.56 \mathrm{a}$ & 12.46 & 11.99 & 9.63 & $11.36 \mathrm{a}$ \\
5 & $13.14 \mathrm{a}$ & $14.81 \mathrm{ab}$ & $11.81 \mathrm{abcd}$ & $13.25 \mathrm{ab}$ & 12.71 & 12.53 & 10.13 & $11.79 \mathrm{a}$ \\
\hline
\end{tabular}

Keterangan: Angka-angka yang diikuti huruf yang sama pada kolom yang sama tidak berbeda nyata pada uji lanjut Tukey-Kramer pada taraf 5\%. M1 = Jan - Mar 2015; M2 = Des 2015 - Feb 2016; M3 = Feb - Mei 2016; ${ }^{+}$Pengaruh interaksi musim dan stadia kematangan nyata pada taraf 0.01 
Tabel 5. Nilai tengah tebal kulit buah dan tebal daging buah untuk tiap stadia kematangan pada tiga musim tanam

\begin{tabular}{lcccccccc}
\hline \multirow{2}{*}{$\begin{array}{l}\text { Stadia } \\
\text { kematangan }\end{array}$} & \multicolumn{3}{c}{ Tebal kulit buah $(\mathrm{cm})$} & \multicolumn{4}{c}{ Tebal daging buah $(\mathrm{cm})$} \\
\cline { 2 - 9 } & M1 & M2 & M3 & Rata-rata & M1 & M2 & M3 & Rata-rata \\
\hline 1 & 0.60 & 0.69 & 0.68 & 0.66 & 1.95 & 1.91 & 1.09 & $1.65 \mathrm{~d}$ \\
2 & 0.63 & 0.75 & 0.61 & 0.66 & 2.17 & 2.09 & 1.23 & $1.83 \mathrm{~cd}$ \\
3 & 0.65 & 0.76 & 0.71 & 0.71 & 2.02 & 2.16 & 1.50 & $1.90 \mathrm{abc}$ \\
4 & 0.69 & 0.73 & 0.69 & 0.70 & 2.16 & 2.38 & 1.55 & $2.03 \mathrm{ab}$ \\
5 & 0.64 & 0.83 & 0.75 & 0.74 & 2.24 & 2.40 & 1.91 & $2.18 \mathrm{a}$ \\
\hline
\end{tabular}

Keterangan: Angka-angka yang diikuti huruf yang sama pada kolom yang sama tidak berbeda nyata pada uji lanjut Tukey-Kramer pada taraf 5\%; M1 = Jan - Mar 2015; M2 = Des 2015 - Feb 2016; M3 = Feb - Mei 2016

Tabel 6. Nilai tengah bobot buah dan padatan terlarut total untuk tiap stadia kematangan pada tiga musim tanam

\begin{tabular}{lcccccccc}
\hline \multirow{2}{*}{$\begin{array}{l}\text { Stadia } \\
\text { kematangan }\end{array}$} & \multicolumn{4}{c}{ Bobot buah $(\mathrm{g})$} & \multicolumn{3}{c}{ Padatan terlarut total $\left({ }^{\circ} \text { Brix }\right)^{+}$} \\
\cline { 2 - 9 } & M1 & M2 & M3 & Rata-rata & M1 & M2 & M3 & Rata-rata \\
\hline 1 & 707.78 & 659.46 & 386.02 & $584.42 \mathrm{c}$ & $7.34 \mathrm{bcd}$ & $4.27 \mathrm{c}$ & $4.34 \mathrm{bcd}$ & $5.32 \mathrm{c}$ \\
2 & 828.15 & 737.63 & 464.42 & $676.73 \mathrm{bc}$ & $7.26 \mathrm{abcd}$ & $4.95 \mathrm{bc}$ & $4.32 \mathrm{bcd}$ & $5.51 \mathrm{c}$ \\
3 & 776.72 & 791.85 & 591.48 & $720.02 \mathrm{~b}$ & $8.00 \mathrm{ab}$ & $5.33 \mathrm{~b}$ & $5.05 \mathrm{abc}$ & $6.13 \mathrm{~b}$ \\
4 & 893.61 & 979.27 & 643.82 & $838.90 \mathrm{a}$ & $7.77 \mathrm{abc}$ & $6.63 \mathrm{a}$ & $5.78 \mathrm{ab}$ & $6.73 \mathrm{~b}$ \\
5 & $1,035.52$ & $1,069.74$ & 690.11 & $931.79 \mathrm{a}$ & $8.36 \mathrm{a}$ & $8.67 \mathrm{a}$ & $7.52 \mathrm{a}$ & $8.18 \mathrm{a}$ \\
\hline
\end{tabular}

Keterangan: Angka-angka yang diikuti huruf yang sama pada kolom yang sama tidak berbeda nyata pada uji lanjut Tukey-Kramer pada taraf 5\%; M1 = Jan - Mar 2015; M2 = Des 2015 - Feb 2016; M3 = Feb - Mei 2016; ${ }^{+}$Pengaruh interaksi musim dan stadia kematangan nyata pada taraf 0.01

Penyusun asam amino aromatik pada buah melon memiliki respon positif terhadap kandungan etilen, sehingga terdapat hubungan antara aroma buah dengan kandungan etilen (Li et al., 2016). Melon tipe reticulatus memiliki aroma buah yang meningkat seiring dengan peningkatan stadia kematangan buah, sedangkan tipe inodorus umumnya tidak menunjukkan adanya aroma buah. Menurut $\mathrm{Oh}$ et al. (2011) aroma volatile pada muskmelon (tipe berjala) mengalami perubahan selama perkembangan buah hingga kematangannya, dan berhubungan dengan produksi etilen dan respirasi. Penelitian ini berupaya mendekati keperluan praktis untuk progam pemuliaan sehingga menggunakan karakteristik morfologi buah untuk membedakan stadia kematangan, dan tidak melakukan analisis yang berkaitan dengan pengaruh etilen terhadap kematangan buah.

Analisis regresi menggambarkan hubungan antara suatu peubah bebas (X, stadia kematangan) dan satu peubah tak bebas (Y, karakter buah yang diamati). Hubungan antara peubah bebas dan peubah terikat tersebut secara kuantitaif dapat dimodelkan dalam suatu persamaan yang kemudian dapat digunakan untuk menduga nilai karakter buah jika diketahui stadia kematangannya (Tabel 7). Besarnya peningkatan nilai karakter buah jika terjadi peningkatan satu stadia kematangan adalah sebesar koefisien regresinya (b). Peningkatan satu stadia kematangan buah diperkirakan meningkatkan bobot buah dan padatan terlarut total masing- masing sebesar $85.69 \mathrm{~g}$ dan $0.69{ }^{\circ}$ Brix (Tabel 7). Pada percobaan ini, estimasi nilai rata-rata bobot buah dan padatan terlarut total pada stadia kematangan 5 adalah $921.75 \mathrm{~g}$ dan $7.76^{\circ}$ Brix. Peningkatan satu stadia kematangan diperkirakan meningkatkan panjang buah $0.45 \mathrm{~cm}$, diameter buah 0.56 $\mathrm{cm}$, tebal daging buah $0.13 \mathrm{~cm}$, dan tebal kulit buah 0.02 $\mathrm{cm}$. Regresi antara bobot buah dan stadia kematangan serta padatan terlarut total dan stadia kematangan ditunjukkan pada Gambar 3 dan 4.

Model regresi linier yang dikembangkan diharapkan dapat bermanfaat bagi program pemuliaan tanaman melon yang dilaksanakan di lingkungan suboptimum yang serupa dengan penelitian ini. Buah-buah melon yang dipanen belum matang karena tanaman layu akibat serangan penyakit atau kondisi suboptimum lainnya dapat diprediksi besaran bobot buah dan padatan terlarut totalnya pada kondisi matang melalui model regresi yang dikembangkan.

Panjang buah berkorelasi nyata terhadap diameter buah dan bobot buah. Bobot buah berkorelasi positif dan sangat nyata dengan panjang buah $(\mathrm{r}=0.53 ; \mathrm{P}<0.01)$, diameter buah $(\mathrm{r}=0.85 ; \mathrm{P}<0.01)$, tebal kulit buah $(\mathrm{r}=0.33 ; \mathrm{P}<0.01)$, dan tebal daging buah $(\mathrm{r}=0.63 ; \mathrm{P}<0.01)$ (Tabel 8). Pada percobaan oleh Manohar dan Murthy (2012), daya simpan buah melon berkorelasi nyata dan positif dengan karakter tebal daging buah $(\mathrm{r}=0.54)$ dan bobot buah $(\mathrm{r}=0.26)$. 


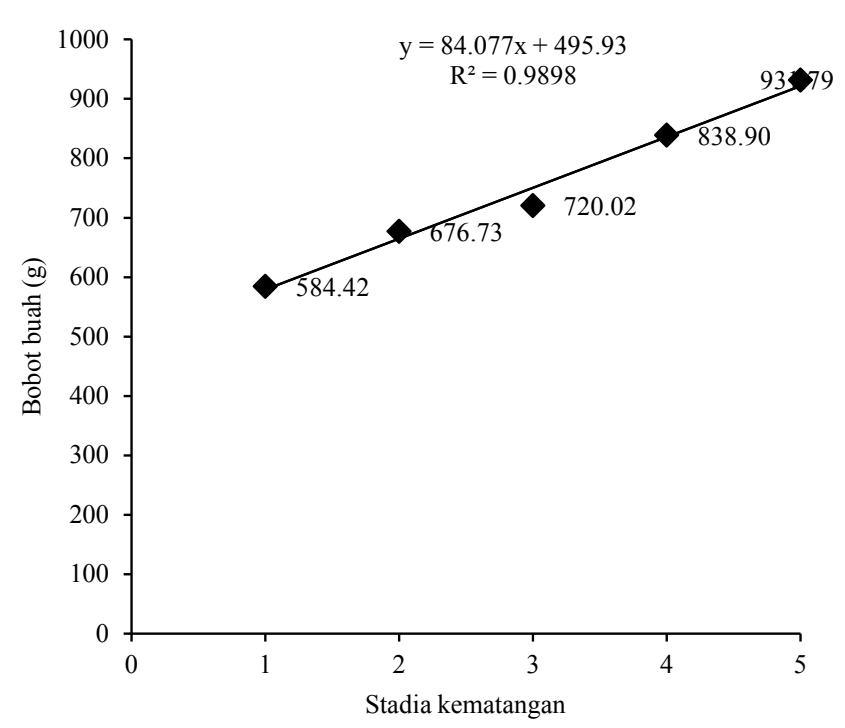

Gambar 3. Regresi bobot buah terhadap stadia kematangan

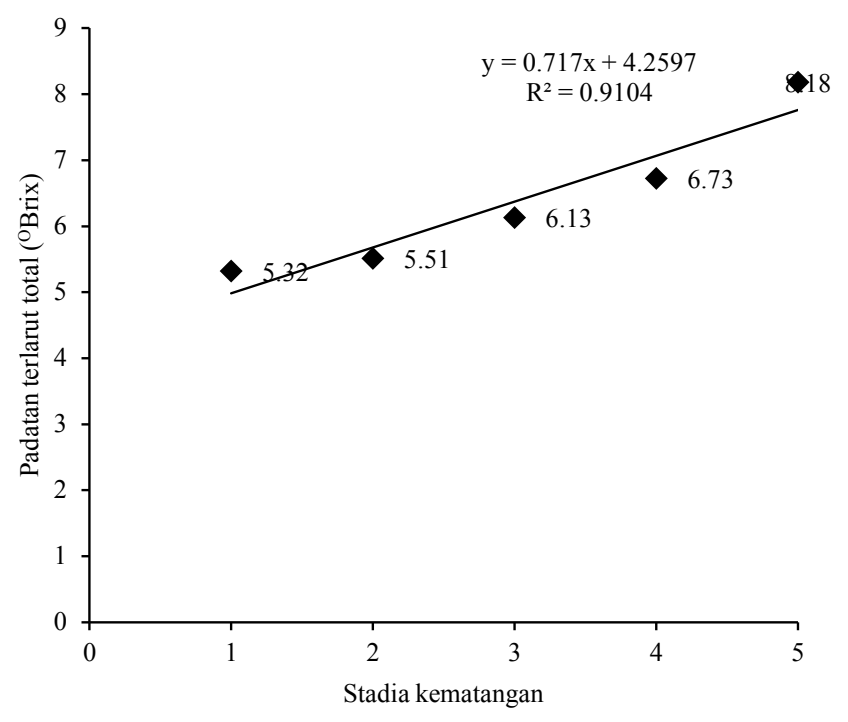

Gambar 4. Regresi padatan terlarut total terhadap stadia kematangan

Tabel 7. Persamaan regresi untuk menduga sifat kuantitatif buah berdasarkan stadia kematangan

\begin{tabular}{llccc}
\hline \multirow{2}{*}{ Karakter } & \multicolumn{1}{c}{ Persamaan regresi } & $\mathrm{R}^{2}$ & \multicolumn{2}{c}{ Nilai P } \\
\cline { 3 - 5 } & & tersesuaikan (\%) & $a$ & 0.023 \\
Panjang buah (PB) & $\mathrm{PB}=11.31+0.45(\mathrm{SK})$ & 81.47 & $<0.0001$ & 0.000 \\
Diameter buah (DB) & $\mathrm{DB}=9.02+0.56(\mathrm{SK})$ & 99.18 & $<0.0001$ & 0.027 \\
Tebal kulit buah (TKB) & $\mathrm{TKB}=0.63+0.02(\mathrm{SK})$ & 79.66 & $<0.0001$ & 0.001 \\
Tebal daging buah (TDB) & $\mathrm{TDB}=1.54+0.13(\mathrm{SK})$ & 98.08 & $<0.0001$ & 0.001 \\
Bobot buah (BB) & $\mathrm{BB}=493.30+85.69(\mathrm{SK})$ & 97.85 & 0.000 & 0.012 \\
Padatan terlarut total (PTT) & $\mathrm{PTT}=4.29+0.69(\mathrm{SK})$ & 87.71 & 0.002 & \\
\hline
\end{tabular}

Keterangan: $a=$ nilai intersep; $b=$ nilai koefisien regresi; $\mathrm{SK}=$ stadia kematangan

Tabel 8. Koefisien korelasi Pearson antar karakter kuantitatif buah $(\mathrm{n}=72)$

\begin{tabular}{llllll}
\hline & PB & DB & TKB & TDB & BB \\
\hline DB & $0.20 \mathrm{tn}$ & & & & \\
TKB & $0.01 \mathrm{tn}$ & $0.39 * *$ & & & \\
TDB & $0.11 \mathrm{tn}$ & $0.69 * *$ & $0.31^{* *}$ & & \\
BB & $0.53^{* *}$ & $0.85 * *$ & $0.33^{* *}$ & $0.63 * *$ & $-0.06 \mathrm{tn}$ \\
PTT & $0.11 \mathrm{tn}$ & $0.17 \mathrm{tn}$ & $-0.27^{*}$ & $\mathrm{tn}$ \\
\hline
\end{tabular}

Keterangan: * berkorelasi nyata pada taraf 5\%;** berkorelasi nyata pada taraf $1 \%$; th tidak berkorelasi nyata; $\mathrm{PB}=$ panjang buah; $\mathrm{DB}=$ diameter buah; $\mathrm{TKB}=$ tebal kulit buah; $\mathrm{TDB}=$ tebal daging buah; $\mathrm{BB}=$ bobot buah; $\mathrm{PTT}=$ padatan terlarut total

\section{KESIMPULAN}

Buah dengan kualitas baik berdasarkan karakter diameter buah, tebal daging buah, bobot buah, dan padatan terlarut total ditunjukkan pada stadia kematangan 5 . Model regresi linier yang diperoleh dapat memprediksi beberapa karakter buah pada stadia kematangan yang berbeda. Peningkatan satu stadia kematangan diperkirakan meningkatkan bobot buah dan padatan terlarut total masing-masing sebesar $85.69 \mathrm{~g}$ dan $0.69^{\circ}$ Brix. Bobot buah berkorelasi positif dan sangat nyata dengan panjang buah $(\mathrm{r}=0.53)$, diameter buah $(\mathrm{r}=0.85)$, tebal kulit buah $(\mathrm{r}=$ $0.33)$, dan tebal daging buah $(\mathrm{r}=0.63)$. Stadia kematangan berpengaruh terhadap kualitas buah sehingga penentuan kriteria panen yang tepat dinilai penting dalam budidaya melon. 


\section{UCAPAN TERIMA KASIH}

Terima kasih disampaikan kepada seluruh teknisi Kebun Percobaan PKHT IPB Tajur II Bogor atas bantuannya dalam pelaksanaan percobaan. Penelitian ini dibiayai dari Hibah Penelitian Strategis Nasional Kementerian Riset, Teknologi, dan Pendidikan Tinggi RI.

\section{DAFTAR PUSTAKA}

Abu-Goukh, A.A., A.F.M. Baraka, M.M.A. Elballa. 2011. Physio-chemical changes during growth and development of 'Galia' cantaloupes. II. Chemical changes. Agric. Biol. J. North America. doi:10.5251/ abjna.2011.2.6.952.963.

Cuevas, H.E., J.E. Staub, P.W. Simon. 2010. Inheritance of beta-carotene-associated mesocarp color and fruit maturity of melon (Cucumis melo L.). Euphytica 173:129-140.

Ezura, H., W.O. Owino. 2008. Melon, an alternative model plant for elucidating fruit ripening. Plant Sci. 175:121-129.

Falah, M.A.F., M.D. Nadine, A. Suryandano. 2015. Effect of storage condition on quality and shelf-life of freshcut melon (Cucumis melo L.) and papaya (Carica papaya). Procedia Food Sci. 3:313-322.

Feyzian, E., H. Dehghani, A.M. Rezai, M.J. Javara. 2009. Diallel cross analysis for maturity and yield-related traits in melon (Cucumis melo L.). Euphytica 168:215-223.

IPGRI. 2003. Descriptors for Melon (Cucumis melo L.). International Plant Genetic Resources Institute, Rome, Italy.

Li, Y., H. Qi, Y. Jin, X. Tian, L. Sui, Y. Qiu. 2016. Role of ethylene in biosynthetic pathway of related-aroma volatiles derived from amino acid in oriental sweet melons (Cucumis melo var. makuwa Makino). Sci Hort. 201:24-35.

Liu, L., F. Kakihara, M. Kato. 2004. Characterization of six varieties of Cucumis melo L. based on morphological and physiological characters, including shelf-life of fruit. Euphytica 135:305-313.
Manohar, S.H., H.N. Murthy. 2012. Estimation of phenotypic divergence in a collection of Cucumis melo, including shelf-life of fruit. Sci Hort. 148:74-82.

Mutton, L.L., B.R. Cullis, A.B. Blakeney. 1981. The objective definition of eating quality in rockmelons (Cucumis melo). J. Sci. Food Agric. 32:385-391.

Oh, S.H., B.S. Lim, S.J. Hong, S.K. Lee. 2011. Aroma volatile changes of netted Muskmelon (Cucumis melo L.) fruit during developmenal stages. Hort. Environ. Biotechnol. 52:590-595.

Pech, J.C., M. Bouzayen, A. Latché. 2008. Climacteric fruit ripening: Ethylen-dependent and independent regulation of ripening pathways in melon fruit. Plant Sci. 175:114-120.

Robinson, R.W., D.S. Decker-Walters. 1999. Cucurbits. CAB International, New York, US.

Senesi, E., L.F.D. Casera, C. Prinzialli, R. Lo Scalzo. 2005. Influence of ripening stage on volatiles composition, physicochemical indexes and sensory evaluation in two varieties of muskmelon (Cucumis melo L. var reticulatus Naud). J. Sci. Food Agric. 85:1241-1251.

Sobir, F.D. Siregar. 2014. Berkebun Melon Unggul. Jakarta (ID): Penebar Swadaya, Jakarta, ID.

Suketi, K., R. Purwanto, S. Sujiprihati, Sobir, W.D. Widodo. 2010. Karakter fisik dan kimia buah pepaya pada stadia kematangan berbeda. J. Agron. Indonesia 38:60-66.

Suwarno, W.B., Sobir, E. Gunawan. 2017. Melon breeding: past experiences and future challenges. p. 16-23. In D. Efendi, A. Maharijaya (Eds.) Proceeding International Seminar on Tropical Horticulture 2016: The Future of Tropical Horticulture. Bogor 28-29 November 2016.

Szamosi, C., I. Solmaz, N. Sari, C. Bársony. 2010. Morphological evaluation and comparison of Hungarian and Turkish melon (Cucumis melo L.) germplasm. Sci Hort. 170-182.

[USDA] United States Departement of Agriculture. 2016. National nutrient database for standard references release 28. https://ndb.nal.usda.gov/ndb/foods/ show/2274. [diunduh 2016 Nov 15]. 